\title{
Using Pixton for Teaching EFL Writing in Higher Education during the Covid-19 Pandemic
}

\author{
Paola Cabrera-Solano \\ Universidad Técnica Particular de Loja, Loja, Ecuador \\ https://orcid.org/0000-0003-3298-6671 \\ Paul Gonzalez-Torres \\ Universidad Técnica Particular de Loja, Loja, Ecuador \\ https://orcid.org/0000-0003-1964-2671 \\ Cesar Ochoa-Cueva \\ Universidad Técnica Particular de Loja, Loja, Ecuador \\ https://orcid.org/0000-0002-9047-3180
}

\begin{abstract}
The study examined the use of Pixton to support the teaching of English as a foreign language (EFL) writing to students at a private university in southern Ecuador. For this purpose, 52 EFL students (male and female, aged 19-24 years old) who were enrolled in a writing course participated in the study for a period of five months. At the start, most of these students had an A1+ proficiency level, according to the Common European Framework of Reference for Languages (CEFR). The study employed an action research design. A diagnostic test was applied at the beginning of the instruction period, and, at the end, a final exam and a perceptions questionnaire were administered. The findings indicate positive perceptions about Pixton, and students' online writing skills improved due to the pedagogical use of this technological tool. Furthermore, Pixton increased students' engagement, motivation and dynamic work to a remarkable extent. Finally, an improvement was observed in aspects of students' writing, such as grammar, vocabulary, coherence and cohesion.
\end{abstract}

Keywords: digital comic strips; EFL writing; perceptions; Pixton; ICT

\section{Introduction}

The Covid-19 pandemic poses enormous challenges to all education systems around the world (Daniel, 2020). This crisis has forced governments and institutions in the public and private sectors to implement several actions to maintain learning continuity during this difficult period. Students have had to use their own resources, and teachers have adapted new pedagogical models to 
deliver teaching during remote learning (Schleicher, 2020). According to Azorín (2020), remote learning is being used to reduce the effects of the crisis on education systems. However, inadequate Internet connections and access to high-speed broadband or digital devices in developing countries is increasing the gap between developed and developing countries. Thus, many higher education institutions all over the world are adapting their curriculum programs to incorporate online or distance learning, since this is a way to meet students' actual needs (Toquero, 2020). In this context, EFL teaching and learning have also faced certain challenges due to the Covid-19 pandemic, which are mainly caused by the abrupt transition to online instruction. Consequently, EFL teachers face problems related to the pedagogical use of technology, materials design, and providing student support (Son, 2018).

Considering the aforementioned context, it is essential that EFL courses implemented under emergency remote teaching set realistic goals for students to acquire language skills through online components (Bailey \& Lee, 2020). In fact, according to Robinson et al. (2016), some linguistic competences are more difficult to manage through online education than others; for example, teaching pronunciation and writing is not an easy task, due to the nature of these skills. With respect to EFL, writing is crucial in language education because it is regarded as one of the most challenging for learners to achieve. Indeed, writing is the most complex skill of the four fundamental English language abilities (writing, reading, speaking and listening), and it is a pivotal aspect for students to master in the foreign language they are learning in order for them to effectively communicate their ideas (Darus \& Ching, 2009).

Because of the importance of mastering writing, effective resources and methods must be used to teach this skill. A current teaching trend is to use technology to foster language acquisition. In the case of the EFL classroom, the implementation of technology in the teaching-learning process has accelerated in recent years, and now provides teachers and students with opportunities to achieve teaching and learning goals effectively (Isnani, 2019).

There are several strategies and technological tools that instructors can use to teach EFL writing skills more effectively. One of those strategies is using comics to promote student engagement while students are learning the target language by means of technology. In this regard, there is a variety of software tools that enable the creation of digital comic strips, such as Cartoon Story Maker, Comic Life, Make Beliefs Comix, Strip Generator, Canva, Clip Studio Paint, Storyboard That, Comicker, ComicBook, Comic Strip Pro, and Comic Creator, though Pixton is popular among Ecuadorian EFL teachers, due to easy access for instructors and students in the Ecuadorian context. Furthermore, Pixton provides opportunities for providing feedback, and sharing and downloading comic strips (Lee, 2013). For this study, we selected Pixton as a resource for students to use to create comic strips to develop their EFL writing competences, and to foster collaborative work, creativity, and critical thinking. 
Studies have examined the use of digital comics for teaching writing in the EFL classroom. Some of these studies have investigated perceptions on the creation of comic strips for learning writing, and reveal positive attitudes towards this activity (Deligianni-Georgaka \& Pouroutidi, 2016; Yasuta, 2018; Puspasari, 2019), and that it encourages language learners to write in English (Hadi et al., 2021). Regarding the use of Pixton, Cabrera et al. (2018) provide evidence of the effectiveness of this tool as a resource to teach EFL grammar and vocabulary two essential components of EFL writing.

Considering the aforementioned aspects, our study focused on using Pixton as a tool to teach EFL writing online. Little formal research into using Pixton as a tool for teaching this skill has been done, especially in the Latin American context. Therefore, we entertained the following research questions:

- How effective is the use of Pixton to support the teaching of online EFL writing?

- How do students perceive the use of Pixton to learn online EFL writing?

\section{Literature Review}

\subsection{Teaching EFL Writing Skills}

Over the last couple of decades, English has become essential for students who live, study and work in a globalized world, which presents various demands in terms of communication (Craig, 2012). According to Rao (2019), English is the only language that is used in almost all fields and for a variety of purposes. In fact, McKay (2002) explains that English is considered to be the language of wide communication across national and cultural boundaries. Furthermore, teaching skills in the target language is fundamental if students are to acquire high proficiency levels in a foreign language (Baturay \& Akar, 2007). However, according to Abdel-Haq and Ali (2017), out of the four language skills, writing plays the most important role, because it demands a great deal of effort and commitment on behalf of the students, who usually struggle with linguistic aspects when they produce texts.

According to Harmer (2004), EFL writing is a process that involves joining several signs and symbols of a language together in order to convey meaning. In this process, learners have to consider important elements that deal with content, organization, grammar and mechanics. However, learning the process of EFL writing is a challenge for students, especially when they are exposed to limited practice time in the classroom, which leads to structural problems, such as choosing the right words, using correct grammar structures, and generating and developing clear ideas about specific topics (Kim \& Kim, 2005). Singh (2019) suggests that EFL students usually struggle with academic writing conventions, such as synthesizing ideas, writing original texts, writing coherent paragraphs, and linking theory to practice. Likewise, Karim et al. (2017) report that some of the most common issues that students face when learning EFL writing relate to brainstorming, choosing appropriate grammar and vocabulary, and planning the different stages of this process. It is clear that writing is one of the most significant skills in EFL instruction (Ghufron \& Ermawati, 2018). 
Considering the relevance of EFL writing skills, instruction by language teachers that help students acquire these abilities is critical, and teachers should be aware of practical procedures that can contribute to students' success. In this respect, Kakan-deea and Kaur (2015) report that, even though there are a number of approaches to writing instruction, not many writing teachers have explicit insights on these approaches. Teachers should be able to enhance students' ability to accomplish communicative competence in writing by means of active sessions that are planned to tackle the students' actual learning difficulties (Ahmed, 2019). With respect to online teaching, different types of resources and tools can be incorporated to promote students' writing fluency in the target language (Fithriani et al., 2018). However, it is important to emphasize that this process needs a great deal of commitment from both teachers and students if it is to achieve effective results.

\subsection{Using Comics to Improve EFL Writing Skills}

Hayman and Pratt (2005) explain that a comic strip is a sequence of discrete, juxtaposed pictures that may or may not include text. However, they distinguish other sequences of juxtaposed pictures when they state that narrative is an essential component of comics. Furthermore, according to Courtis (2008), comics can build meaningful learning environments that encourage students to write texts according to their own personalities and artistic values. Moreover, Yunus et al. (2012) assert that using digital comics stimulates students' interest in writing. They also believe that using comics as a tool for learning a language is an effective way to teach writing to students with low English proficiency levels. Other researchers such as Themelis and Sime (2020) posit that comics allow for creativity in English teaching, which motivates students to a significant extent. Furthermore, Susilawati (2017) states that teaching writing by means of digital comics can capture learners' attention, facilitate comprehension of class material, encourage students to learn, expand creative thinking skills, and increase learners' passion for learning. For instance, designing comics using Toondoo encourages students to be creative and produce different writing genres by considering the required elements and features of each genre. Learners can also express their own feelings, emotions, concepts, and beliefs, and come up with creative stories and poems. Thus, it is important to focus on creative writing techniques through the application of ICTs, instead of having lessons imparted by traditional methods (Tahsaldar \& Semaan, 2018). Moreover, Wahyudin (2019) claims that using digital comics benefits students, as they can develop their writing skills in terms of content and organization.

In addition, using comics has a significant effect on students' writing ability. For this reason, it is important to include different types of activities and also to apply various teaching strategies to create a good classroom atmosphere when using comics for teaching EFL writing (Ridhwan \& Ihsan, 2018). Thus, creating digital comics with the purpose of telling stories could turn EFL writing into a much more entertaining learning process.

\subsection{Pixton as a Resource for Teaching EFL Writing}

The purpose of Pixton is creating comic strips. One of the advantages of Pixton is that this software tool runs on all operating systems and offers a free license, 
athough the free version only provides a limited use of the different functions, which could limit learners' creativity when they design their own comic strips (Meyers, 2014). Some advantages of Pixton include a user-friendly environment and a variety of characters, backgrounds, panels, movements, expressions, and editing tools. This tool allows users to have codes for embedding, to download the files as pictures, to access it anywhere where there is an Internet connection, and to share files with others who are not Pixton users (Purnomo, 2017).

As a technological resource, Pixton has great potential to enhance the teachinglearning process, due to the feature of enabling students to create comics easily on a digital platform, and have control over the content they created. In this respect, researchers have been able to determine that comics can help learners have a positive attitude towards learning and to increase motivation (Kılıçkaya \& Krajka, 2012). The benefits of using these types of tools are evident in the field of language learning, where computer-based material can help teachers achieve their language teaching objectives, which translates into students improving their achievements in, understanding of, and performance in the target language (Faridah et al., 2020).

Although formal research on Pixton for teaching EFL writing is not a widely explored field, there are studies that have analysed Pixton for certain purposes, such as teaching EFL grammar and vocabulary (e.g., Cabrera et al., 2018). It is also important to mention that there have been studies conducted on using other digital comic strip makers as resources to teach EFL/ English as a Second Language (ESL) writing. These studies demonstrate positive attitudes towards comic strip creation for teaching EFL writing (Muyassaroh et al., 2019; Hadi et al., 2021), and acknowledge that digital comics can attract and encourage language learners to write in English (Puspasari, 2019). In the next section, we will discuss these studies in more depth.

\subsection{Studies on Using Pixton for Language Teaching}

A study by Deligianni-Georgaka and Pouroutidi (2016) focused on combining technology with writing, as an alternative technique to motivate students to write. This research investigated whether creating stories by using digital comics enhanced learners' interest in writing in English, and whether it helped them to develop their writing abilities. This research was done via a case study, in which a class of sixth graders in primary education participated. Observations, interviews and questionnaires were used to collect data. The results were positive regarding combining technology and writing and, specifically, creating digital comics in the classroom. The findings show that creating digital comics promoted teamwork and collaborative writing, and created positive feelings in students.

Yasuta (2018) demonstrated the potential of implementing a project-based activity using an online comic creator in the EFL classroom. The main purpose of this project was to stimulate the intellectual curiosity of 44 students of English and change their attitudes toward learning and interacting with other students. The participants worked on a group project throughout the course, and created Japanese/English comics aimed at contributing to the revitalization of a disaster- 
hit community. For this purpose, an online comic creator was used to develop a series of writing activities. The results revealed that using the comic creator was perceived by students as a fascinating experience that positively changed their perspective toward group work and learning English.

Muyassaroh et al. (2019) explored a teacher's perceptions, practices, and problems regarding using digital comics to teach writing. Participants were 60 high school vocational students and an English teacher. A case study research design was used. Data were gathered through semistructured interviews, class observations, the teacher's syllabus, lesson plans, comics and the students' writing tasks. The findings indicate that the teacher perceived the use of comics to be the best approach to helping students change their views on English (from a difficult course to an interesting one). Nonetheless, using digital comics along with a process approach was a challenging experience due to limited class time. The time was not enough, because implementing digital comics needs the support of electronic tools, such as laptops, projectors, and screens.

Puspasari (2019) carried out an exploratory study that examined teachers' opinions about the implementation of digital comics in the EFL teaching and learning process. Participants were 30 teachers of English who had been exposed to digital comics and had used them in their classroom. A 20-item survey questionnaire was used, and it investigated three main types of perceptions: using ICTs, advantages and limitations of using digital comics, and applying digital comics for teaching EFL. The findings indicate that the participants had favorable perceptions about the implementation of digital comics in teaching and learning of English. Furthermore, using digital comics encouraged students, increased their interest, and helped them learn English creatively by promoting an engaging environment.

Hadi et al. (2021) investigated the effectiveness of Mangarock (an online comic media application) to improve students' writing skills. Participants were 200 ninth-grade students divided into five classes in Indonesia. This research used a quantitative approach, which included a pre-experimental design. Researchers gathered data by means of writing tests. A t-test was applied to determine the efficacy of using Mangarock online comics. In addition, descriptive statistical analysis measured the students' writing skills through pre-tests and post-tests. Different learning approaches, such as a product-based learning approach, a process-based learning approach, and a genre-based learning approach, were used to support students in generating narrative texts. The results indicate that learning activities using Mangarock online comics was effective in improving students' writing skills.

Considering the aforementioned studies, we conclude that formal research about using Pixton as a resource to teach online EFL writing is scarce, especially in the Latin American context. Therefore, our study attempted to provide greater insights into this field. 


\section{Method}

\subsection{Setting and participants}

This study was conducted at a private university in Ecuador. The participants were selected through purposeful sampling. The sample consisted of 52 male and female EFL students, aged 19-24 years. They were in the only class at the university taking a writing course as part of a Teaching English as a Foreign Language program. The majority of them had an A1+ proficiency level, according to the Common European Framework of Reference for Languages (CEFR) (Council of Europe, 2020). This level was determined by applying the ExamEnglish (2019) placement test. This course taught productive writing skills by employing a communicative teaching approach. This study was conducted for five months, and the participants received English instruction during a total of 30 online sessions (40 minutes per session twice a week).

\subsection{Instruments}

After designing the surveys, they were subjected to a process of checking their validity and reliability by piloting the questionnaires with a group of 10 students, who were enrolled in other courses of the EFL program, before they were administered for the study sample. After correcting some errors found in the questionnaires, we applied the Cronbach's alpha to measure internal consistency of the items. In the case of our questionnaires, we obtained a Cronbach's alpha coefficient of 0.7. After this process, we decided to use the following instruments in our study.

- An online placement test was administered to determine the participants' proficiency level before the intervention process started. This test was the ExamEnglish (2019), which is aligned with the CEFR.

- A pre-training questionnaire, which consisted of six closed-ended and one open-ended questions, was used to identify the participants' previous writing skills experience, and their experience of using technological tools for learning writing. This instrument was based on the study by Puspasari (2019), and it was administered as an online questionnaire.

- An online diagnostic test was administered to students to determine their level of writing skills in English. This test design used materials for teaching EFL writing. The test required students to respond to open-ended questions and write short paragraphs that were graded with a rubric.

- A final online exam with the same characteristics as the diagnostic test was applied at the end of the course, to verify the participants' improvement in writing skills after the instruction period.

- A post-questionnaire was applied to the participants to determine their opinions on the use of Pixton as a resource for learning EFL writing. This instrument was designed according to the study by Puspasari (2019), it was administered online, and it consisted of four objective questions and nine items that elicited responses on a Likert scale.

\subsection{Research Design}

This study used an action research design with a quantitative approach, because we collected data to evaluate and analyze a teaching strategy to improve instruction (Creswell \& Creswell, 2017). According to Klein (2012), a quantitative 
method in action research can provide evidence about students' improvement after using a new strategy in the classroom. Additionally, since we were interested in students' perceptions about the use of Pixton as a tool to improve English writing skills, we also applied a survey design, which is another procedure in quantitative research (Creswell \& Creswell, 2017). It is worth mentioning that there was an open-ended question in the pre-training questionnaire that would count as gathering qualitative data.

\subsection{Procedure}

Before starting the application of instruments, we obtained the students' consent to participate in this research. In addition, the questionnaires guaranteed that participants' anonymity would be maintained, and that information would be treated as confidential. The process started by administration of the ExamEnglish (2019) placement test, which enabled us to obtain an immediate indication of the students' proficiency levels. This was an online test that was easy to administer, and it was delivered at the beginning of the course. We determined that the majority of the students had an A1+ proficiency level. An online diagnostic test was also administered to determine students' level of English writing skills, which was the starting point for designing the activities of the course. Additionally, a pre-training questionnaire was applied to identify the students' perceptions about their EFL writing skills, and about the use of technological tools.

After obtaining the results of this first stage, we conducted an instruction process, which was carried out through the Virtual Learning Management Platform (Canvas). First students had to open accounts on Pixton. Then, we requested students to create comic strips on topics that we selected according to their needs, competences and learning outcomes, which were set out in the syllabus of the course. The focus of the syllabus was to learn vocabulary, grammar structures, and coherence and cohesion. In this regard, students created a total of 10 comic strips individually, which were presented and explained to the class by means of the platform Zoom, and the corresponding teacher's feedback was obtained.

At the end of the instruction period, students took a final online exam to determine their achievement level in EFL writing skills. These results were compared with the results obtained in the diagnostic test. Later, they completed a questionnaire about their perceptions on the use of Pixton as a resource for learning this skill. The data from the placement test, diagnostic tests, final exams and questionnaires were organized and tabulated, and the results were assessed according to the aspects studied in the syllabus and relating to the students' written production. As for the pre- and post-test results, the Student's t-test was applied to observe the statistical significance of the difference between the students' scores before and after instruction.

\section{Results and Discussion}

The results of the ExamEnglish (2019) placement test indicated that 47 students had an A1+ proficiency level, 4 were on the A2 level, and only 1 student had a B1 level. With respect to the results of the pre-training questionnaire, the majority of the students (83\%) had previously used technological tools to learn English. The 
most common tools used by instructors to teach writing and identified by students were PowerPoint presentations $(74 \%)$, online shared documents $(8 \%)$, forums $(7 \%)$, social networks $(5 \%)$, and videos, audio recordings, podcasts, and others (6\%). As for students' writing performance, 63\% rated themselves as good, $14 \%$ as very good, and $23 \%$ mentioned that they needed improvement. The students' diagnostic test results indicated an average score of 5.2 out of 10 points, which means that they, indeed, required a solution to enhance their writing skills.

After the training process, students were administered a final test and a posttraining questionnaire. On the final test, students obtained an average score of 7.8 out of 10 points. We applied the Student's t-test (see Table 1) to determine the significance of the difference between the pre and post-tests, and we obtained a p-value $<.05$, which means that the difference is significant. This means that incorporating Pixton in the students' training was an important factor that enhanced their writing skills.

Table 1. Results of the Student's t-test applied to the scores of the pre and post test

\begin{tabular}{|l|c|c|}
\hline & Pre-test & Post-test \\
\hline Mean & 5.2 & 7.8 \\
\hline SD & 2.046 & 1.858 \\
\hline p-value & \multicolumn{2}{|c|}{0.00005706} \\
\hline
\end{tabular}

Figure 1 compares writing exam scores. It is clear that the aspect that improved the most is organization of ideas.

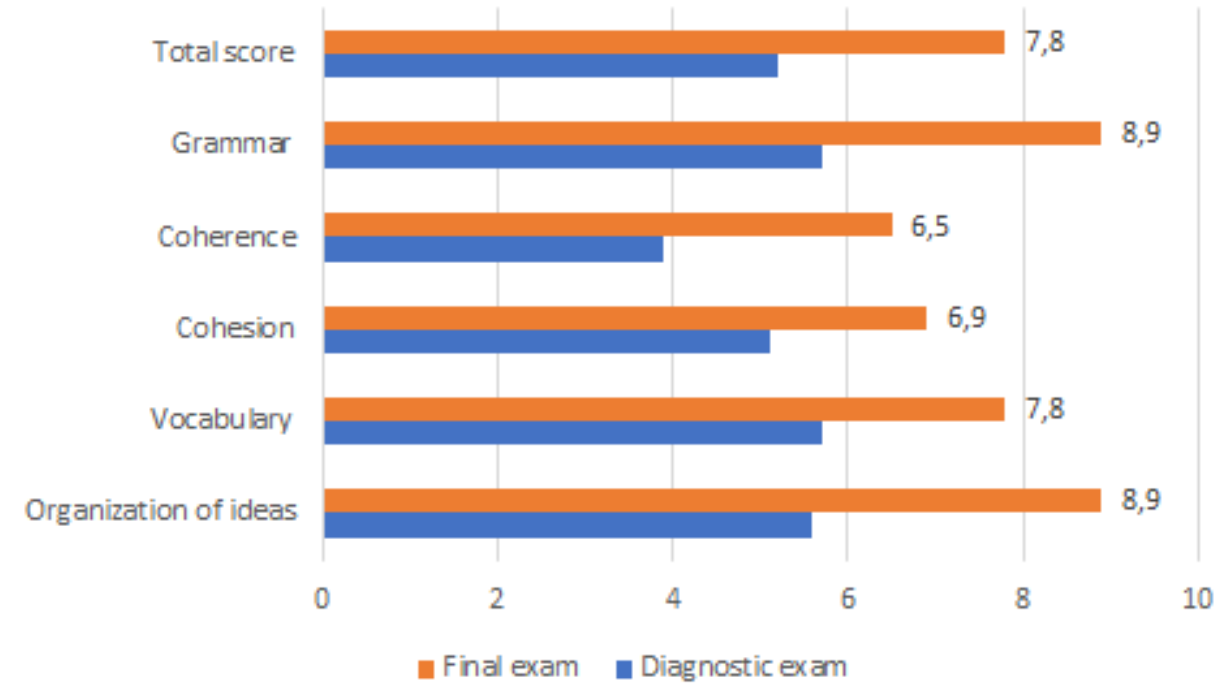

Figure 1. Comparison of the writing exam scores

An aspect that enhances writing skills is positive peer feedback on the creation of digital comic strips. Another aspect is students' motivation at the moment of executing activities related to EFL grammar and writing and using these types of comics (Kılıçkaya \& Krajka, 2012).

With respect to the students' post-training questionnaire, the results showed general satisfaction about using Pixton as a tool for developing their writing skills. 
In this regard, Pixton could improve students' performance in EFL writing skills, depending on their proficiency level (Castillo et al., 2018). Likewise, as Table 2 shows, according to students' perceptions about the use of Pixton, most of them were totally satisfied with its use, since it developed their writing skills, allowed them to write coherently, and helped them to practice grammar and vocabulary. In confirmation, Megawati and Anugerahwati (2012) assert that using comic strips can help EFL learners to structure and generate ideas and choose accurate grammar, vocabulary, and punctuation.

Similarly, students claimed that using this tool enabled them to be more involved in the activities of the course, since they were engaged and worked more dynamically when they used Pixton. Indeed, comic strips can involve students in the learning process by helping them to visually analyze and actively reflect on the topics to be learned (Popa \& Tarabuzan, 2015). In addition, our results indicate that students' interest and motivation increased through using this tool. Finally, the majority of students were very satisfied with Pixton, since it allowed them to show their knowledge of the course.

Table 2. Students' perceptions on the use of Pixton

\begin{tabular}{|c|c|c|c|c|c|}
\hline Items & 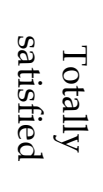 & 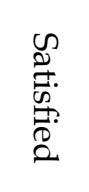 & 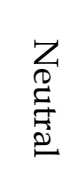 & 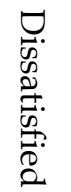 & 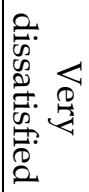 \\
\hline Pixton was useful for developing my writing skills & $82 \%$ & $9 \%$ & $6 \%$ & $3 \%$ & $0 \%$ \\
\hline $\begin{array}{l}\text { Pixton enabled me to be involved in the activities } \\
\text { of the subject }\end{array}$ & $68 \%$ & $16 \%$ & $10 \%$ & $6 \%$ & $0 \%$ \\
\hline $\begin{array}{l}\text { My interest in the course increased due to the use } \\
\text { of Pixton }\end{array}$ & $59 \%$ & $28 \%$ & $7 \%$ & $6 \%$ & $0 \%$ \\
\hline Pixton allows me to write coherently & $50 \%$ & $24 \%$ & $20 \%$ & $6 \%$ & $0 \%$ \\
\hline $\begin{array}{l}\text { Pixton was useful to put grammar and vocabulary } \\
\text { into practice }\end{array}$ & $77 \%$ & $10 \%$ & $7 \%$ & $6 \%$ & $0 \%$ \\
\hline $\begin{array}{l}\text { The use of Pixton motivated me to do the activities } \\
\text { in the subject }\end{array}$ & $64 \%$ & $8 \%$ & $22 \%$ & $6 \%$ & $0 \%$ \\
\hline $\begin{array}{l}\text { My attention level on the activities of the subject } \\
\text { increased due to the use of Pixton }\end{array}$ & $64 \%$ & $10 \%$ & $20 \%$ & $6 \%$ & $0 \%$ \\
\hline Pixton allowed me to do dynamic work & $82 \%$ & $8 \%$ & $4 \%$ & $6 \%$ & $0 \%$ \\
\hline $\begin{array}{l}\text { Pixton enabled me to show my knowledge of the } \\
\text { course }\end{array}$ & $52 \%$ & $20 \%$ & $22 \%$ & $6 \%$ & $0 \%$ \\
\hline
\end{tabular}




\section{Conclusions and Pedagogical Implications}

At the start of the study, students' EFL writing skills were poor, as indicated by the results of the diagnostic test. Consequently, the intervention process, which involved students creating comic strips on Pixton, with the necessary teaching support, helped them to achieve a considerable improvement in their online writing abilities, as measured by EFL proficiency level. Teaching support for using Pixton was fundamental for enhancing students' engagement and motivation and the dynamism of their work.

The second finding is that students had positive perceptions regarding using Pixton because they believed that designing comics online helped them to pay more attention to the contents of the class, to be more involved in class activities, to write coherently, and increase their interest in the course, among other factors conducive to acquiring EFL writing skills.

In the third place, using Pixton helped students to improve their EFL writing skills, because it enabled them to increase their ability to organize ideas, and improved other aspects of writing, such as grammar, vocabulary, coherence and cohesion. This resource also engaged students in dynamic and interesting activities. Therefore, there was a remarkable increase in the students' motivation for their writing lessons. Finally, most EFL teachers only use basic resources, such as PowerPoint presentations. Only a small number of teachers have used resources such as online shared documents, forums, social networks, videos, audio recordings, and podcasts. This means that using innovative technological resources was not common in this sample of participants. Therefore, this study provides evidence that Pixton is an effective tool for improving teaching of EFL writing skills, especially in higher education.

Finally, there was only one class enrolled in this EFL writing course, so this is one limitation of this study. Further research regarding the use of digital comics for teaching EFL writing should be conducted by employing an experimental research design, which may result in findings that could be generalizable in other, similar contexts. Moreover, these studies should be oriented to remote learning situations, to address teaching in the current Covid-19 pandemic.

\section{Acknowledgements}

The authors of this research would like to acknowledge Universidad Tecnica Particular de Loja for promoting and supporting this study through the EFL Learning, Teaching and Technology Research Group.

\section{References}

Abdel-Haq, E., \& Ali, H. (2017). Utilizing the corpus approach in developing EFL writing skills. Journal of Research in Curriculum Instruction and Educational Technology, 3(2), 11-44. https:/ / doi.org/ 10.21608/jrciet.2017.24458

Ahmed, P. (2019). Major writing challenges experienced by EFL learners in Soran University. Journal of University of Human Development, 5(3), 120-126. https://doi.org/10.21928/juhd.v5n3y2019.pp120-126 
Azorín, C. (2020). Beyond COVID-19 supernova. Is another education coming? Journal of Professional Capital and Community, 381. https://doi.org/10.1108/JPCC-05-20200019

Bailey, D., \& Lee, A. (2020). Learning from experience in the midst of Covid-19: benefits, challenges, and strategies in online teaching. Computer-Assisted Language Learning Electronic Journal, 21(2), 178-198.

Baturay, H., \& Nurgun, A. (2007). A new perspective for the integration of skills to reading. Dil Dergisi, 136, 16-27.

Cabrera, P., Castillo, L., González, P., Quiñónez, A., \& Ochoa, C. (2018). The impact of using Pixton for teaching grammar and vocabulary in the EFL Ecuadorian context. Teaching English with Technology, 18(1), 53-76.

Castillo, L., Quiñonez, A., Cabrera, P., Gonzalez, P., \& Ochoa, C. (2019). Using digital educational comics for learning EFL vocabulary. In P. Vélez \& Y. Yaguana (Eds.), Nuevas tecnologías en el proceso de enseñanza-aprendizaje [New technologies in the teaching-learning process], pp. 11-14. Dialnet, Universidad de la Rioja.

Council of Europe (2020). Common European framework of reference for languages: learning, teaching, assessment - Companion volume. Council of Europe Publishing.

Courtis, A. (2008). 6 Tech Module: Using Comic Life in the classroom. Creative Commons. https://cnx.org/contents/1n435fck@10.1:xzq3jocL@1/Tech-Module-UsingComic-Life-in-the-Classroom

Craig, J. (2012). Integrating writing strategies in EFL/ESL university contexts: A writing-acrossthe-curriculum approach. Routledge.

Creswell, J. W., \& Creswell, J. D. (2017). Research design: Qualitative, quantitative, and mixed methods approaches. Sage Publications.

Daniel, J. (2020). Education and the COVID-19 pandemic. Prospects, 49(1), 91-96. https://doi.org/10.1007/s11125-020-09464-3

Darus, S., \& Ching, K. (2009). Common errors in written English essays of form one Chinese students: A case study. European Journal of Social Sciences, 10(2), 242-253.

Deligianni-Georgaka, A., \& Pouroutidi, O. (2016). Creating digital comics to motivate young learners to write: A case study. Research Papers in Language Teaching and Learning, 7(1), 233.

ExamEnglish.com (2019). Test your level of English vocabulary. https://www.examenglish.com/leveltest/grammar_level_test.htm

Faridah, D., Irianti, L., \& Fachriyani, R. (2020). Investigating pre-service English teachers' perception on the use of multimedia in EFL teaching and learning process: Pedagogical implication. Jadila: Journal of Development and Innovation in Language and Literature Education, 1(2), 2019-222. https:// doi.org/10.52690/jadila.v1i2.102

Fithriani, R., Rafida, T., \& Siahaan, A. (2019). Integrating online blogging into EFL writing instruction: Exploring students' perceptions. UNNES International Conference on English Language Teaching, Literature, and Translation (ELTLT 2018) (pp. 87-90). Atlantis Press. https://doi.org/10.2991/eltlt-18.2019.17

Ghufron, M., \& Ermawati, S. (2018). The strengths and weaknesses of cooperative learning and problem-based learning in EFL writing class: Teachers' and students' perspectives. International Journal of Instruction, 11(4), 657-672. https://doi.org/10.12973/iji.2018.11441a

Hadi, M., Izzah, L., \& Larasati, I. (2021). The influence of Mangarock online comics in teaching writing a narrative text. Journal of Languages and Language Teaching, 9(2), 243-249. https:// doi.org/10.33394/jollt.v\%vi\%i.3546

Harmer, J. (2004). How to teach writing. Pearson Longman.

Hayman, G., \& Pratt, H. (2005). "What Are Comics?" A Reader in Philosophy of the Arts. Pearson Education. 
Isnani, K. (2019). A study among English teachers' perceptions: Investigating the roles of ICT in Indonesian EFL classroom. English, Teaching, Learning, and Research Journal, 5(2), 247-253.

Ka-kan-deea, M., \& Kaur, S. (2015). Teaching strategies used by Thai EFL lecturers to teach argumentative writing. Procedia-Social and Behavioral Sciences, 208, 143-156. https://doi.org/10.1016/j.sbspro.2015.11.191

Karim, S., Maasum, T., \& Latif, H. (2018). Writing challenges of Bangladeshi tertiary level EFL learners. $e$-Bangi, 14(2).

Kılıçkaya, F., Krajka, J. (2012). Can the use of web-based comic strip creation tool facilitate EFL learners' grammar and sentence writing? British Journal of Educational Technology, 43(6), 161-165. https:// doi.org/10.1111/j.1467-8535.2012.01298.x

Kim, Y., \& Kim, J. (2005). Teaching Korean university writing class. Asian EFL, 7(2), 1-15. https://doi.org/10.12691/education-3-7-3

Klein, S. (2012). Action research: before you dive in, read this! In S. S. Klein (Ed.), Action research methods (pp. 1-20). Palgrave Macmillan. https://doi.org/10.1057/9781137046635_1

Lee, V. W. H. (2013). Using Pixton as a tool in the classroom. ETEC 510 [wiki]. http://etec.ctlt.ubc.ca/510wiki/Using_Pixton_As_a_Tool_in_the_Classroom

McKay, S. L. (2002). Teaching English as an international language: Rethinking goals and approaches. Oxford University Press.

Megawati, F., \& Anugerahwati, M. (2012). Comic strips: a study on the teaching of writing narrative texts to Indonesian EFL students. TEFLIN Journal, 23(2), 183-205.

Meyers, E. (2014). Theory, technology, and creative practice: using Pixton comics to teach communication theory. Communication Teacher, 28(1), 32-38. https://doi.org/10.1080/17404622.2013.839051

Muyassaroh, M., Asib, A., \& Marmanto, S. (2019). The teacher's beliefs and practices on the use of digital comics in teaching writing: A qualitative case study. International Journal of Language Teaching and Education, 3(1), 45-60. https://doi.org/10.22437/ijolte.v3i1.6502

Popa, N., \& Tarabuzan, E. O. (2015). Using comic strips in teaching and learning French as foreign language: Changes in motivational beliefs. Review of Artistic Education, (9/10), 273.

Purnomo, M. (2017). The effectiveness of Pixton to improve students' narrative writing ability at MTs Sabilul Muttaqin Pungging Mojokerto (Doctoral dissertation, UIN Sunan Ampel Surabaya).

Puspasari, D. (2019). Digital comics in English language teaching. Proceedings of Annual International Conference on Islamic Education and Language: Education 4.0 and Industrial Era in Islamic Perspective, 7-14. http://jurnal.uinbanten.ac.id/index.php/aiciel/article/view/2588

Rao, P. (2019). The importance of English in the modern era. Asian Journal of Multidimensional Research (AJMR), 8(1), 7-19. https://doi.org/10.5958/22784853.2019.00001.6

Ridhwan, M., \& Ihsan, M. (2018). The effect of comic strips on secondary EFL students' reading comprehension and writing ability. EJI (English Journal of Indragiri): Studies in Education, Literature, and Linguistics, 2(2), 43-57. https://doi.org/10.32520/eji.v2i2.236

Robinson-Cimpian, J., Thompson, K., \& Umansky, I. (2016). Research and policy considerations for English learner equity. Policy Insights from the Behavioral and Brain Sciences, 3(1), 129-137.

Schleicher, A. (2020). The impact of Covid-19 on education. Insights from education at a glance 2020. OECD. https://www. oecd. org/education/the-impact-of-covid-19-oneducation-insights-education-at-a-glance-2020. pdf 
Singh, M. (2019). Academic reading and writing challenges among international EFL Master's students in a Malaysian university: The voice of lecturers. Journal of International Students, 9(4), 972-992. https://doi.org/10.32674/jis.v9i3.934

Son, J. B. (2018). Technology in English as a Foreign Language (EFL) Teaching. In J. I. Liontas (Ed.), The TESOL Encyclopedia of English Language Teaching. Wiley. https://doi.org/10.1002/9781118784235.eelt0448

Susilawati, F. (2017). Teaching writing of narrative text through digital comic. Journal of English and Education, 5(2), 103-111.

Tahsaldar, M., \& Semaan, C. (2018). The impact of Toondoo comics on undergraduate students taking creative writing and children literature courses at the Lebanese University Faculty of Pedagogy. International Journal of Humanities Social Sciences and Education (IJHSSE), 5(8), 203-226. http://dx.doi.org/10.20431/2349-0381.05080019

Themelis, C., \& Sime, J. (2020). From video-conferencing to holoportation and haptics: How emerging technologies can enhance presence in online education. In S. Yu, M. Ally, \& A. Thinakos (Eds.), Emerging technologies and pedagogies in the curriculum (pp. 261-276). Springer.

Toquero, C. (2020). Challenges and Opportunities for Higher Education Amid the COVID19 Pandemic: The Philippine Context. Pedagogical Research, 5(4). https://doi.org/10.29333/pr/7947

Wahyudin, A. (2019). E-comics in teaching: Using comic strip creators to enhance junior high school students' writing ability. In G. Putrawan, \& R. Deviyanti (Eds.), Proceedings of the 2nd ICON ELTL, Bandar Lampung: November 16, 2019. (pp. 126-133). University of Lampung. http://repository.lppm.unila.ac.id/18748/1/Proceedings_2nd_ICON_ELTL_2019 _CETAK_OK_Rev5c.pdf\#page $=140$

Yasuta, T. (2018). Online Comic Creator for EFL writing: An effective tool for collaborative learning. 11th Innovation in Language Learning International Conference, Florence, 369370. https://conference.pixel-online.net/ICT4LL/files/ict4ll/ed0011/FP/5119SLA3430-FP-ICT4LL11.pdf

Yunus, M, Salehi, H., \& Embi, M. (2012). Effects of using digital comics to improve ESL writing. Research Journal of Applied Sciences, Engineering and Technology, 4(18), 3462 3469 . 